Jurnal Homepage: http:/journal2.um.ac.id/index.php/jaa (p-ISSN: 2087-9695; e-ISSN: 2580-1015)

\title{
Transformasi praktik akuntansi Usaha Mikro, Kecil, Menengah (UMKM): dari memori ke catatan
}

\author{
Dian Syariati ${ }^{1}$, Unti Ludigdo ${ }^{2}$, Ali Djamhuri ${ }^{2}$ \\ ${ }^{1}$ Universitas Negeri Malang, Jl. Semarang No. 5, Malang, Indonesia \\ ${ }^{2}$ Universitas Brawijaya, Jl. Veteran No. 12-14, Malang, Indonesia
}

Diterima: 29 Mei 2020 Direvisi: 30 Juni 2020 Disetujui: 2 Juli 2020

Koresponding:

Dian Syariati

dian.syariati.fe@um.ac.id

\section{DOI:}

http://dx.doi.org/10.17977/ um004v7i22020p133

\begin{abstract}
Accounting is the language of business. Changes that occur in business certainly have an impact on accounting. Previous research on accounting practices only explains existing accounting practices without linking these changes with business changes. This research explores the forms of accounting changes caused by business changes in manufacture in Micro, Small and Medium Enterprises (MSMEs). Manufacturing companies are chosen with consideration of business complexity which leads to a greater requirement for accounting practices. The research result shows a transformation of MSMEs's accounting practices related to the business changes. Task delegation is a factor that drives the transformation of accounting practices from relying on memory to records. Fairness becomes a value in the transformation of this accounting practice.
\end{abstract}

Keywords: Transformation; Accounting Practices; Task Delegation; Notes; Memory

\begin{abstract}
Abstrak
Akuntansi adalah bahasa bisnis. Perubahan yang terjadi pada bisnis tentu berdampak pada akuntansi. Penelitian tentang praktik akuntansi sebelumnya hanya menjelaskan praktik akuntansi yang ada tanpa mengaitkan perubahan tersebut dengan perubahan bisnis. Penelitian ini menggali bentuk perubahan akuntansi yang diakibatkan oleh perubahan bisnis pada Usaha Mikro, Kecil dan Menengah (UMKM) di sektor manufaktur. Perusahaan manufaktur dipilih dengan pertimbangan kompleksitas bisnis yang mengarah pada kebutuhan yang lebih besar untuk praktik akuntansi. Hasil penelitian menunjukkan adanya transformasi praktik akuntansi UMKM terkait perubahan bisnis yang dijalani. Pendelegasian tugas menjadi faktor yang mendorong transformasi praktik akuntansi dari sebatas mengandalkan memori ke catatan. Keadilan menjadi nilai penyerta dalam transformasi praktik akuntansi ini.

Kata kunci: Transformasi; Praktik Akuntansi; Pendelegasian Tugas; Catatan; Memori
\end{abstract}

\section{PENDAHULUAN}

Akuntansi terbukti berperan besar bagi UMKM dimana diantaranya yaitu membantu untuk mengontrol kinerja dan mengambil keputusan (Failian, 2012); mengetahui naik turunnya laba usaha, pemasukan, pengeluaran, grafik penjualan dan produksi (Mulyani, 2018); serta mengukur rasio profitabilitas (Nyathi et al., 2018). Sebaliknya, lemahnya akuntansi menjadi salah satu faktor penyebab kegagalan UMKM untuk berkembang (Gaskill et al, 1993). Sehubungan dengan peran ini, maka akuntansi juga dikenal sebagai bahasa bisnis. Akuntansi sebagai bahasa bisnis menunjukkan peran akuntansi dalam menyediakan informasi bagi pihak yang berkepentingan terkait pengambilan keputusan bisnis. Hal tersebut berarti akuntansi tidak bisa dipisahkan dari pengelolaan bisnis.

Akuntansi dipraktikkan oleh UMKM dalam berbagai bentuk. Di Zimbabwe, sebagian besar UMKM tidak memiliki catatan akuntansi yang lengkap. Catatan akuntansi yang dimiliki diantaranya berupa buku pembelian harian, buku penjualan harian, buku pengeluaran, catatan penggajian serta catatan aset (Maseko, 2011). Praktik ini terjadi karena lemahnya pengetahuan akuntansi dan (persepsi) ketidakefisiensian informasi akuntansi dalam mengukur kinerja keuangan. Catatan akuntansi yang tidak lengkap juga ditemukan di UMKM di Nigeria (Ezeagba, 2017) dan Sri Lanka (Madurapperuma et al., 2016). Penyebab ketidaklengkapan ini adalah kurangnya pengetahuan akuntansi, tingginya biaya mempekerjakan seorang akuntan profesional dan ketiadaan transaksi yang terkait dengan sistem perbankan. Di Ghana, meskipun sebagian besar UMKM tidak memiliki catatan keuangan, UMKM yang memiliki catatan keuangan lebih suka menggunakan jotters dan catatan pribadi (Mbroh \&

Cara mengutip: Syariati, D., Ludigdo, U., \& Djamhuri, A. (2020). Transformasi praktik akuntansi Usaha Mikro, Kecil, Menengah (UMKM): dari memori ke catatan. Jurnal Akuntansi Aktual. 7(2), 133-144. 
Assah, 2015). Beberapa alasan kepemilikan catatan keuangan adalah a) mengetahui kinerja bisnis, b) membantu pengambilan keputusan, c) memberikan informasi kepada pihak luar, serta d) mengelola bisnis dengan baik. Sesuai dengan penelitian Asaduzzaman (2016) yang menemukan hanya sejumlah kecil UMKM di Bangladesh yang memiliki catatan akuntansi dalam bentuk laporan laba rugi, laporan bank, neraca, laporan arus kas serta laporan perubahan posisi keuangan. Sebagian besar UMKM tidak membuat catatan akuntansi karena kesulitan dan juga (merasa) tidak perlu meskipun harus membayar pajak lebih besar. Di Kenya, sebagian besar UMKM menggunakan sistem pencatatan ganda (double entry systems) (Chelimo \& Sopia, 2014).

Praktik akuntansi UMKM di Indonesia dapat dipotret pada dua titik yaitu sebelum dan sesudah terbitnya SAK EMKM. Sebelum penerbitan SAK EMKM, beberapa hasil penelitian oleh Alfitri et al., 2013; Pambudi \& Adam, 2013; Andriani et al., 2014; Lutfiaazahra, 2015; Saragih \& Surikayanti, 2015; Fatwa, 2016; Nurlela \& Elvia, 2016; Norkamsiah et al., 2016; Darmayanti et al., 2017 menemukan kegagalan UMKM untuk menerapkan Standar Akuntansi Keuangan Entitas Tanpa Akuntabilitas Publik (SAKETAP) yang pada saat itu juga mencakup akuntansi UMKM. Hal ini disebabkan akuntansi dipraktikkan oleh UMKM dengan cara yang lebih sederhana dibandingkan dengan tuntutan standar yang berlaku. Kegagalan untuk menerapkan SAK ETAP ini telah diprediksi terjadi (Rudiantoro \& Siregar, 2012). Laily (2013) menambahkan bahwa UMKM tidak memiliki pembukuan formal. Praktik akuntansi UMKM selanjutnya pada titik yang kedua yaitu setelah penerbitan SAK EMKM juga tidak jauh berbeda. UMKM dinilai masih belum berhasil mengimplementasikan standar yang ada (Haryanti et al., 2019; Nuvitasari et al., 2019). Dalam hal ini, akuntansi UMKM hanya melakukan pencatatan atas semua biaya dan pendapatan.

Hasil studi di atas menarik untuk dipelajari lebih lanjut terkait dengan alasan mengapa akuntansi dipraktikan dalam berbagai bentuk dan sering tidak sesuai dengan standar. Dalam bingkai teori institusional, akuntansi yang dipraktikkan oleh organisasi dipengaruhi oleh faktor eksternal dan internal organisasi (Zucker, 1987 \& Fogarty, 1996). Sesuai dengan pernyataan tersebut, Hopwood et al., (1994) juga menyatakan bahwa budaya, kebiasaan, norma dan institusi menentukan keberadaan akuntansi. Berkenaan dengan peran akuntansi sebagai bahasa bisnis, akuntansi tentu akan berubah seiring dengan perubahan bisnis tersebut. Dengan kata lain, perubahan bisnis menuntut perubahan akuntansi. Penelitian terdahulu lebih banyak membahas tentang bentuk praktik akuntansi yang ada tanpa mengaitkan perubahan tersebut dengan perubahan bisnis sedangkan akuntansi sangat terkait dengan perkembangan bisnis. Penelitian ini menggali perubahan praktik akuntansi UMKM dengan mengaitkan pada perubahan bisnis yang terjadi. Secara praktis, pengetahuan ini akan memberikan kontribusi dalam menemukan peran terbaik akuntansi bagi UMKM. Informan dalam penelitian ini adalah UMKM manufaktur yang telah mengalami perubahan dalam pola bisnis. UMKM manufaktur dipilih dengan pertimbangan kompleksitas bisnis yang mengarah pada kebutuhan yang lebih besar untuk praktik akuntansi dibandingkan UMKM yang bergerak di bidang dagang maupun jasa.

\section{METODE}

Penelitian ini adalah penelitian kualitatif yang menjelaskan bagaimana perubahan praktik akuntansi UMKM manufaktur terkait perubahan bisnis yang dialami. Fenomenologi transendental atau sering hanya disebut fenomenologi atau ilmu penglihatan/fenomena (Adian, 2010) digunakan untuk memahami bagaimana perubahan tersebut terjadi. Pemahaman tidak berhenti pada apa yang dilihat tetapi berlanjut ke makna perubahan praktik akuntansi. Dalam hal ini, kesadaran yang diberikan langsung kepada peneliti atau intuisi yang memainkan peran penting dalam membentuk makna (Patton, 2002; Moleong, 2000).

Informan pertama penelitian adalah Angga yang merupakan pemilik bisnis roti "Angga" di Malang dengan latar belakang pendidikan sarjana hukum dan tidak memiliki kredit bisnis di bank Informan penelitian kedua adalah Anggi yang merupakan adik perempuan Angga yang terlibat dalam kegiatan bisnis. Perusahaan manufaktur dipilih dengan pertimbangan kompleksitas kegiatan bisnis (dibandingkan dengan perusahaan perdagangan dan jasa). Kompleksitas ini mendorong permintaan praktik akuntansi yang lebih besar. UMKM Angga dipilih karena telah mengalami perubahan pola bisnis, mulai dari pengelolaan bisnis secara pribadi hingga pendelegasian pengelolaan bisnis kepada karyawan. Penentuan informan juga ditentukan oleh kemudahan akses data. Kemudahan akses data berarti tidak ada data tersembunyi atau sengaja disembunyikan oleh informan. Hal ini berkontribusi pada akuisisi pemahaman lengkap tentang perubahan praktik akuntansi UMKM.

Lebih rinci, proses penelitian dilakukan dalam 3 tahap, yaitu tahap pra-lapangan, tahap lapangan dan tahap pasca-lapangan. Tahap pra-lapangan dilakukan melalui tinjauan literatur terkait praktik akuntansi UMKM serta pengamatan awal untuk menemukan informan yang sesuai. Tahap lapangan adalah tahap pengumpulan data melalui wawancara dan observasi. Wawancara dilakukan 
dalam format yang tidak terstruktur dalam bahasa sehari-hari (campuran Jawa-Indonesia). Wawancara tentang suatu topik berlangsung terus-menerus sehingga tidak ada perspektif baru yang diungkapkan oleh informan mengenai topik tersebut. Pengumpulan data juga dilakukan melalui observasi. Pengamatan dimulai dengan melihat langsung pada kegiatan bisnis yang dilakukan oleh informan. Data yang dihasilkan dari wawancara dan observasi diceritakan dalam catatan lapangan yang tidak hanya berisi catatan deskriptif, tetapi juga catatan reflektif yang berisi presentasi, perasaan dan kesan (Groenewald, 2004). Penelitian ini menggunakan bantuan media elektronik untuk mengabadikan data penelitian. Penggunaan media ini dilakukan setelah mendapatkan persetujuan dari informan.

Tahap pasca-lapangan adalah analisis data dengan pendekatan fenomenologis yaitu epoche, reduksi fenomenologi, variasi imajinasi dan sintesis makna serta esensi (Kuswarno, 2009). Epoche berarti bahwa para peneliti untuk sementara waktu meninggalkan semua pengetahuan tentang praktik-praktik akuntansi UMKM untuk mendapatkan perspektif baru. Reduksi fenomenologis dilakukan dengan mengidentifikasi praktik akuntansi UMKM manufaktur berdasarkan aktivitas bisnis masing-masing. Pada tahap ini, tinjauan literatur dan interaksi dengan pihak lain juga dilakukan untuk mendapatkan berbagai sudut pandang yang berguna dalam mengklarifikasi fenomena. Namun pada tahap ini, peneliti juga mencoba menemukan fenomena murni terlepas dari hasil tinjauan literatur dan persepsi orang lain. Hasil dari fase ini adalah pemahaman tentang apa yang tampak dari perubahan praktik akuntansi informan. Variasi imajinasi dilakukan untuk mendapatkan esensi dari perubahan praktik akuntansi informan. Intuisi digunakan dalam penelitian ini untuk mencapai makna perubahan praktik akuntansi informan berdasarkan pada apa yang telah diperoleh pada tahap reduksi fenomenologis. Dalam hal ini, peneliti bergerak dari apa yang tampak menuju kesadaran. Sintesis makna dan esensi adalah proses integrasi pemahaman tentang apa yang dilihat dari perubahan praktik akuntansi informan dan makna yang terkandung di dalam praktik tersebut. Kombinasi kedua hal itu merupakan jawaban tentang bagaimana bentuk perubahan praktik akuntansi informan terkait dengan perubahan pola bisnis yang dialami.

\section{HASIL DAN PEMBAHASAN}

\section{Pola Bisnis dan Praktik Akuntansi: Transformasi Praktik Akuntansi}

Peran akuntansi sebagai bahasa bisnis menuntut perubahan akuntansi yang mengikuti perubahan bisnis yang ada. Transformasi mengacu pada perubahan praktik akuntansi dari fase ke fase. Fenomena ini pernah diungkapkan oleh Hopwood et al., (1994) yang menjelaskan bahwa akuntansi tidak dapat dilepaskan dari lingkungan sebagaimana organisme tidak dapat dipisahkan dari habitat. Dalam konteks penelitian ini, praktik akuntansi memengaruhi dan dipengaruhi oleh perubahan dalam bisnis. Hal ini dijelaskan oleh tiga fase yang dilalui perusahaan dalam Gambar 1. Fase pertama menunjukkan pemilik bisnis yang terlibat dalam kegiatan produksi dan pemasaran memiliki ketergantungan pada kemampuan dan (mungkin) intuisi untuk membuat keputusan. Pada fase kedua, pemilik bisnis tidak terlibat langsung dalam kegiatan bisnis dan akuntansi yang dipraktikkan dalam catatan. Dalam hal ini, catatan digunakan sebagai penyedia informasi untuk pengambilan keputusan terkait dengan pengendalian kegiatan bisnis, harga jual produk, gaji karyawan serta informasi keuntungan bisnis. Selanjutnya fase ketiga menunjukkan karyawan mulai mengabaikan kepentingan terbaik perusahaan dimana akuntansi tidak dapat berfungsi sebagai solusi. Dalam hal ini, pemilik bisnis menambahkan kontrak kerja untuk melengkapi keberadaan catatan kas, catatan produksi dan catatan pemasaran sebagai alat pengendalian. Transformasi praktik akuntansi ini mendukung teori institusional yang menyebut perilaku organisasi (dalam hal ini akuntansi) yang dipengaruhi oleh faktor eksternal dan internal (Zucker, 1987 \& Fogarty, 1996). Transformasi praktik akuntansi ditunjukkan pada Gambar 1 .

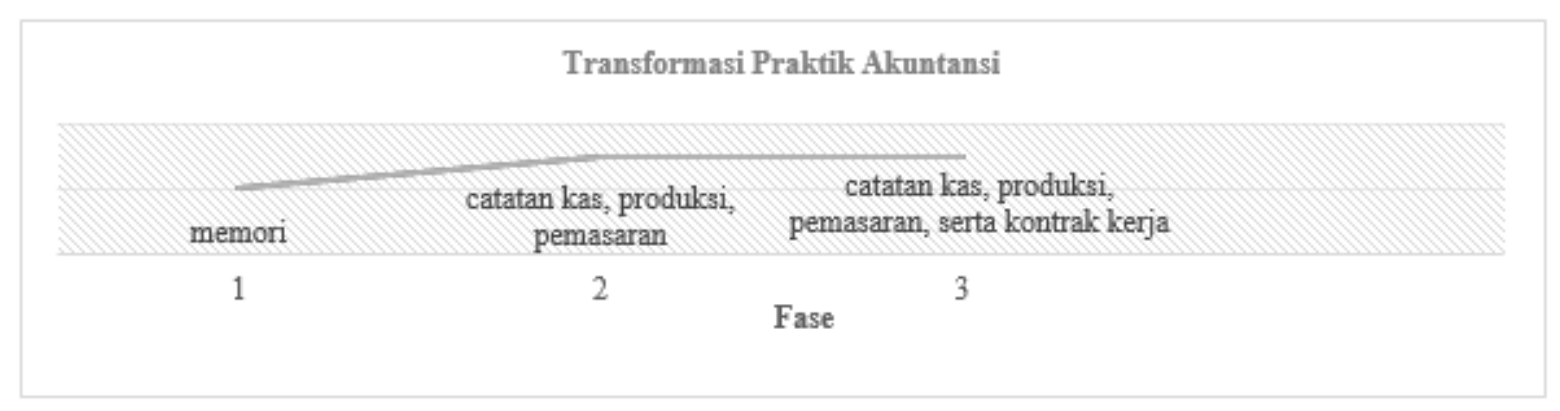

Gambar 1. Transformasi Praktik Akuntansi 
Berdasarkan uraian di atas, pendelegasian tugas merupakan motivasi perubahan praktik akuntansi. Pendelegasian tugas menyebabkan pergeseran posisi pemilik bisnis dan karyawan dalam menjalankan aktivitas bisnis. Pemisahan pemilik dari kegiatan bisnis mengakibatkan kurangnya informasi tentang aktivitas bisnis yang sedang atau telah berjalan. Dalam hal ini, karyawan sebagai pelaku kegiatan bisnis sehari-hari memiliki akses informasi yang lebih besar dibandingkan dengan pemilik bisnis yang tidak terlibat langsung dengan kegiatan bisnis atau terjadi asimetri informasi (Scott, 2003). Perbedaan akses informasi ini mengarah pada kemungkinan bahwa karyawan tidak selalu bertindak sesuai kepentingan terbaik pemilik bisnis (Jensen \& Meckling, 1976). Hal ini juga disadari oleh Angga melalui pernyataan sebagai berikut:

"Soalnya kan repotnya aku kan gak di sana jadi aku bisa ngecek buat berapa-kirim berapa,

bukannya buatnya banyak terus kirimnya sedikit. Seng salah di mana? Apa rotinya rusak? Apa dia ngakali aku?..."

Terjemahan: "karena repotnya saya tidak di sana jadi saya bisa mengecek buat berapa-kirim berapa, bukan buat banyak terus kirim sedikit. Yang salah di mana? Apa rotinya rusak? Apa dia menyurangi saya?"

Angga menyadari bahwa keputusan untuk tidak berpartisipasi dalam kegiatan bisnis menyebabkan kesulitan dalam memastikan keakuratan proses produksi dan pemasaran. Ketidakakuratan dalam proses produksi dan pemasaran dapat disebabkan oleh penyimpangan karyawan yang tidak bertindak sesuai kepentingan terbaik perusahaan. Pemisahan antara pemilik bisnis dan karyawan juga dipahami sebagai penyebab ketidakpercayaan yang mendorong pemilik bisnis untuk mencari kepastian informasi atau penghindaran ketidakpastian (Hofstede, 1999). Dengan kata lain, pemilik bisnis akan mengambil tindakan untuk menghindari ketidakpastian dalam informasi bisnis dimana salah satunya melalui catatan akuntansi. Hal ini sebagaimana tercermin dalam pernyataan berikut:

"Saya kan dulu yo ono se punya rencana keuangan punya, rencana pencatatan punya tapi gak jalan karena waktu itu saya nangani sendiri kan-di dapur terus lah kadang kirim dewe, duwite tak tompo-tak tompo dewe tapikan kalau sekarang saya mencoba memisahkan diri. Oleh karena itu ya hanya catatan itu wes andalane akhire"

Terjemahan: "Saya dulu punya rencana keuangan, rencana pencatatan punya tapi tidak berjalan karena waktu itu saya menangani sendiri (produksi) di dapur terus terkadang saya kirim sendiri, uangnya (hasil penjualan) saya terima sendiri tapikan kalau sekarang saya mencoba memisahkan diri. Oleh karena itu, hanya catatan itu andalannya”.

Berdasarkan penjelasan di atas, catatan menjadi komponen penting untuk mengetahui kondisi bisnis karena pemilik memutuskan untuk tidak menangani kegiatan bisnis secara langsung. Catatan memberikan informasi penting yang terjadi dalam bisnis seperti jumlah produk yang dibuat, jumlah bahan yang digunakan, jumlah produk yang dijual, serta jumlah produk yang tersisa. Dalam hal ini, karyawan hanya memiliki peran memasukkan data sesuai dengan informasi yang diminta oleh pemilik bisnis dalam catatan. Informasi ini ditentukan oleh pemilik bisnis berdasarkan kebutuhannya akan informasi terkait, mengingat pemilik bisnis tidak memiliki kewajiban untuk mempertanggungjawabkan kegiatan usaha kepada pihak lain. Oleh karena itu, ketergantungan pemilik bisnis pada informasi dalam catatan menjadi sangat besar. Posisi catatan dalam bisnis pada fase kedua dan ketiga (setelah pendelegasian tugas) terlihat pada Gambar 2.

\section{Akuntansi pada fase pertama bisnis: memori sebagai panduan pengambilan keputusan}

Pernyataan di bawah ini menegaskan karakteristik umum UMKM dimana pemilik UMKM menangani sendiri kegiatan usaha dan tidak membutuhkan catatan.

"...Iha makane de'e iku kan ditangani dewe kan mulai tekan produksi-produksi dewe, dodolandodolan dewe, kulakan-kulakan dewe makane de'e iku gak butuh laporan opo iku jenenge catatan-catatan karena dia percaya pada de'e dewe. Toh iso ngerasakno kan, bati opo gak kan iso ngerasakno...”

Terjemahan: "...Iha karena dia itu kan menangani sendiri mulai dari produksi, penjualan, pembelian bahan, karena itu dia tidak membutuhkan laporan atau apa itu namanya catatan-catatan karena dia percaya pada dirinya sendiri. Kan bisa merasakan, untung atau tidak kan bisa merasakan”.

Hal ini dilatarbelakangi asumsi kecukupan informasi yang dimiliki pemilik terkait usaha yang dijalankan serta asumsi kerepotan yang harus ditanggung oleh pemilik jika terdapat keberadaan catatan. Proses mencatat yang diyakini sebagai definisi akuntansi diakui merupakan kegiatan tambahan yang dilakukan untuk memastikan ketepatan proses produksi dan pemasaran serta mengetahui besaran laba. Keterlibatan langsung pemilik dalam kegiatan usaha menjadikan tujuan ini dapat terpenuhi meskipun tidak dilakukan proses pencatatan. Sehubungan dengan hal tersebut, pemilik usaha secara tidak langsung mengakui kemampuan diri sendiri dalam mengelola kegiatan usaha tanpa bantuan catatan. 


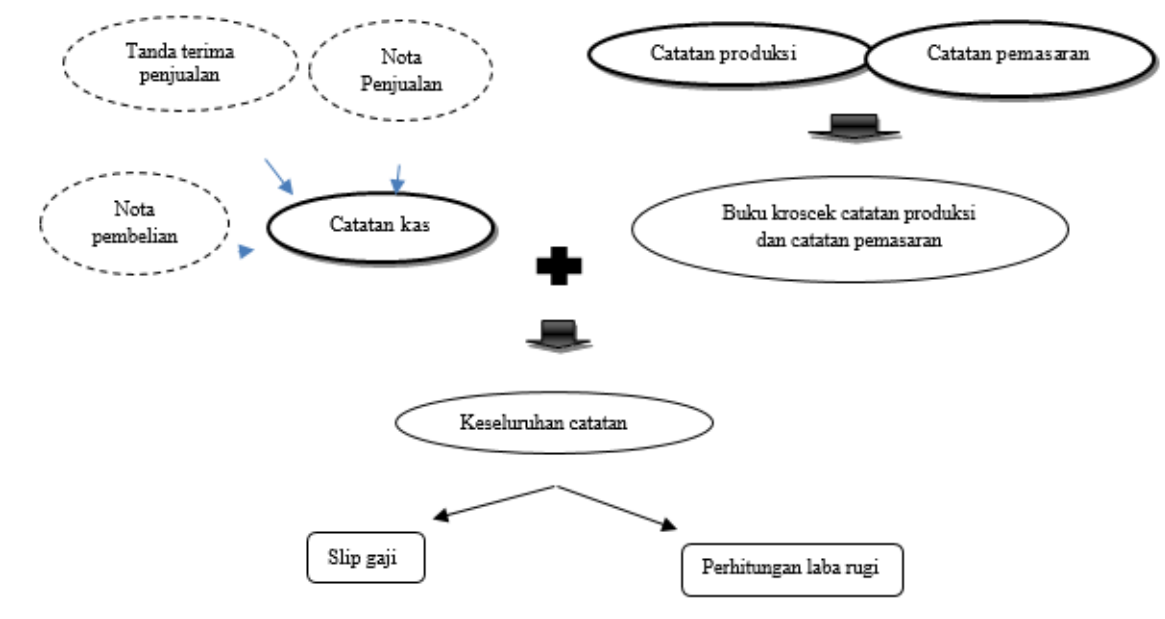

Gambar 2. Posisi Catatan dalam Bisnis pada Fase Dua dan Tiga

Keterangan

c=- Bukti Pendukung

Diisi atau dilengkapi oleh karyawan

Dibuat oleh pemilik

Hal ini dilatarbelakangi asumsi kecukupan informasi yang dimiliki pemilik terkait usaha yang dijalankan serta asumsi kerepotan yang harus ditanggung oleh pemilik jika terdapat keberadaan catatan. Proses mencatat yang diyakini sebagai definisi akuntansi diakui merupakan kegiatan tambahan yang dilakukan untuk memastikan ketepatan proses produksi dan pemasaran serta mengetahui besaran laba. Keterlibatan langsung pemilik dalam kegiatan usaha menjadikan tujuan ini dapat terpenuhi meskipun tidak dilakukan proses pencatatan. Sehubungan dengan hal tersebut, pemilik usaha secara tidak langsung mengakui kemampuan diri sendiri dalam mengelola kegiatan usaha tanpa bantuan catatan.

Fenomena yang dialami pemilik usaha (informan) bisa menunjukkan bahwa pemilik usaha sebenarnya telah melaksanakan akuntansi meskipun dalam ruang lingkup yang kecil. Penelaahan terhadap hasil penelitian Mbogo (2011), Maseko (2011), Ezeagba (2017), Madurapperuma et al., (2016), Mbroh \& Assah (2015), Asaduzzaman (2016) serta Chelimo \& Sopia (2014) menunjukkan praktik akuntansi pada usaha UMKM selalu dihubungkan dengan pengelolaan keuangan usaha, angka, perhitungan serta laporan. Berkenaan dengan hal ini, akuntansi mungkin dipraktikkan dalam bentuk lain oleh informan meskipun dilakukan tanpa catatan.

Diantara pengelolaan keuangan usaha yang dilakukan informan tanpa catatan adalah penyusunan biaya produksi yang terdiri atas harga pembelian bahan baku dari produk. Komposisi biaya produksi ini tentu berbeda dengan konsep yang umum dipelajari yaitu penentuan biaya produksi melibatkan catatan dengan unsur-unsur penyusun biaya produksi yang terdiri atas biaya produksi bahan langsung, tenaga kerja langsung dan overhead. Untuk mendapatkan harga jual produk, biaya produksi selanjutnya ditambahkan ke keuntungan yang diinginkan oleh informan. Dalam konteks yang lebih besar, keuntungan bisnis diartikan sebagai perbedaan antara hasil penjualan dan pengeluaran. Dengan demikian, keberadaan uang tunai merupakan dasar penentuan laba. Hal ini dapat dipahami berdasarkan tujuan informan dalam melihat keuntungan. Keuntungan yang dihitung oleh pemilik bisnis UMKM digunakan untuk tujuan pribadi. Pemilik usaha tidak memiliki minat untuk memberi tahu pihak lain mengenai jumlah keuntungan. Dengan demikian, perhitungan laba secara tunai telah memenuhi kebutuhan pemilik bisnis. Ketiadaan dorongan eksternal atau paksaan mengenai bentuk akuntansi yang harus dipraktikkan telah diungkapkan oleh Jacobs dan Kemp (2002) sebagai salah satu penyebab kesulitan menemukan praktik akuntansi sesuai standar pada pedagang mikro di Bangladesh maupun Sri langka (Madurapperuma et al., 2016).

\section{Akuntansi pada fase kedua bisnis: catatan sebagai alat pengendalian}

Pengendalian merupakan fungsi utama catatan. Pengendalian dimaksudkan agar karyawan bertindak sesuai kepentingan terbaik perusahaan yang sekaligus kepentingan terbaik pemilik usaha. Angga mengakui bahwa ketidakhadirannya dalam kegiatan bisnis memungkinkan karyawan untuk mengambil tindakan yang menyimpang dari kepentingan terbaik perusahaan. Dalam hal ini, catatan 
kas, catatan produksi dan catatan pemasaran adalah alat untuk memastikan efektivitas dan efisiensi kegiatan bisnis sebagaimana dinyatakan oleh Angga sebagai berikut:

“...maksude tidak menangani langsung lama kelamaan dia pengen melepas atau mendelegasikan tugas-tugasnya dia. Misalkan tugas produksinya dia, dia delegasikan. Otomatis yang dikasi delegasi itu harus melaporkan dengan catatan-catatan. Pakai bahan berapa jadinya berapa, terus yang bagian pemasaran itu juga gitu”

“...ada teman yang di dapur iku tak pasrahi jurnal kas... Dia (kepala produksi) kadang juga nerima penjualan, kadang yo langsung tak pek duwek e, ada yang dia, tiap hari iku ada aja wes, terus sama dia kulakan. Kalau kulakan ya dia yang beli, pake uang dari yang setoran tadi. Kalau misalkan kurang yo berarti aku seng nambahi tapi yo dicatet sama dia tekan aku, tapi lek aku butuh yo tak ambil, dia catete prive. Jadi biasa setiap seminggu sekali-sekarang tak usahakan tiap seminggu sekali tapi kalau dulu sebulan sekali jurnalnya dia tak cek gitu lo sekaligus sama notanya. Jadi misalkan beli kulakan di toko bahan-tak cek notanya-tak coret-coret, yang gak ada notanya ya tak tanyakan...”

"Pemasaran itu punya jurnal sendiri, jadi misalkan ada dua orang ya tiap selesai kerja dicatati lagi di buku pemasaran jadi total akhirnya berapa ketemu, berapa dia ngirim berapa, produksi berapa kan kelihatan. Soalnya kan repotnya aku kan gak di sana jadi aku bisa ngecek buat berapa-kirim berapa, bukannya buatnya banyak trus kirimnya sedikit. Seng salah di mana? Apa rotinya rusak? Apa dia ngakali aku?".

Alat untuk memastikan efektivitas dan efisiensi bisni yang pertama adalah dalam bentuk catatan kas. Catatan kas merupakan dokumentasi gabungan dari uang tunai yang diterima oleh departemen pemasaran dan uang tunai yang dikeluarkan oleh departemen produksi. Catatan kas dibuat oleh kepala produksi untuk melaporkan hasil penjualan, pembelian bahan, penarikan atau penambahan modal oleh pemilik serta hutang karyawan. Informasi dalam catatan kas secara khusus berfungsi sebagai pengendalian atas pengeluaran dan pemasukan kas. Pengendalian pengeluaran kas dilakukan untuk memastikan ketepatan penggunaan kas, jumlah kas keluar serta personel yang bertanggung jawab atas pengeluaran tersebut. Sementara pengendalian pemasukan kas dilakukan untuk memastikan kesesuaian jumlah kas masuk serta personel yang bertanggung jawab atas penerimaan kas tersebut. Setiap minggu, pemilik bisnis melakukan pemeriksaan untuk menguji kesesuaian informasi dalam catatan kas dengan bukti pendukung. Ketidaksesuaian informasi akan ditindaklanjuti dengan konfirmasi kepada pihak terkait.

Alat kedua berhubungan dengan catatan produksi. Catatan produksi juga merupakan tanggung jawab kepala produksi. Catatan ini berisi informasi tentang jumlah produksi adonan, jumlah roti jadi dan rusak, presensi personil, waktu produksi (mulai dan selesai), sirkulasi LPG serta masalah pemesanan. Catatan produksi dimaksudkan untuk memastikan efisiensi produksi dalam hal penggunaan bahan serta waktu produksi. Penggunaan bahan dikatakan efisien ketika telah memenuhi perbandingan terbaik input dan output pembuatan roti, yakni 75 roti per adonan. Standar ini merupakan hasil pengalaman pemilik bisnis pada fase pertama pengelolaan bisnis.

Alat ketiga yaitu catatan pemasaran. Catatan pemasaran merupakan dokumentasi kegiatan pemasaran yang ditandai dengan pengiriman roti kepada pelanggan. Catatan pemasaran berisi laporan kurir mengenai lokasi pengiriman, jumlah pengiriman, pengembalian serta uang yang diterima. Catatan ini merupakan gabungan catatan yang dimiliki oleh masing-masing kurir. Dokumen yang mendukung catatan ini adalah catatan penjualan dan tanda terima penjualan. Pengiriman roti merupakan kegiatan penting karena informan tidak memiliki toko pribadi untuk menjual roti hingga saat ini. Kepastian pengiriman produk ke pelanggan serta kepastian kuantitas yang dikirim adalah hal yang dicari melalui keberadaan catatan pemasaran.

\section{Akuntansi pada fase kedua bisnis: catatan sebagai sumber informasi harga jual produk dan gaji karyawan \\ Petikan wawancara di bawah ini secara tidak langsung mengungkapkan bahwa catatan merupakan sumber informasi penentuan harga jual produk. Harga jual produk dibentuk oleh biaya bahan dan (mungkin juga) biaya LPG serta tenaga kerja. Harga jual produk selanjutnya juga mempertimbangkan efisiensi produksi. Informasi harga bahan diperoleh dari catatan kas sedangkan informasi efisiensi produksi diperoleh dari catatan produksi.}

Peneliti: "Iha lek samean nentukan harga satu roti, yok opo cara e mas?? Ko iso dapat 2000 iku yok opo?"

Terjemahan: "kalau anda menentukan harga roti, bagaimana caranya? Bisa dapat (harga) Rp2.000 itu, bagaimana caranya?”. 
Angga: "Yo harga pokok bahan, tapi setiap rasa kan laen, roti rasa ini, sama roti rasa ini kan laen kan, yo ono range e ae 800-1000"

Terjemahan: "ya harga pokok bahan tapi setiap rasa lain, roti rasa ini dengan roti rasa ini lain, ya ada kisarannya antara Rp800 sampai Rp1.000”.

Angga: "...aku nentukan 1000 itu sudah ada catatane-buku kecil-tak cari-cari gak ketemu, itu sudah termasuk LPG sama tenaga apa belum lupa aku, makane mau tak itung lagi". “...pengen ngitung lagi jadi misalkan e...nimbang itu berapa lama, terus tak itung ngasi meses untuk isian itu berapa lama, gramnya berapa, tak update lagi jadi kita nentuin hpp cek genah ngunu lo, soale kene ngitunge ojo lupa lo dari 2000 kan tuipis a iki, misalkan 1000 moro-moro 1300 ..."

Terjemahan: "ingin menghitung lagi, misalkan menimbang itu berapa lama, terus menghitung lagi (untuk) memberi isian meses itu berapa lama, gramnya berapa, saya perbaharui lagi (informasinya) jadi kita menentukan harga pokok produksi biar benar, karena saya menghitungnya jangan lupa lo dari (harga) Rp2.000 kan tipis, misalkan Rp1.000 tiba-tiba (hitungan hpp-nya) Rp1.300)”.

Penghitungan ulang biaya produksi dilakukan dengan meninjau ulang upah kurir. Hal ini dilakukan mengingat keengganan pasar untuk menerima kenaikan harga. Rencana evaluasi sistem penggajian disebutkan Angga sebagai berikut:

Peneliti: "Kira-kira kalau seumpamanya dikasi harga di atas 2000 gitu, pasare kiro-kiro sek mau a mas? Misalkan seng ndek sekolahan samean naikno, kiro-kiro nanti ordere kiro-kiro bakal tetep?"

Terjemahan: (kira-kira kalau ditetapkan harga di atas Rp2.000, pasarnya masih mau menerima? Misalkan yang di sekolah dinaikkan (harganya), kira-kira permintaannya tetap?).

Angga: "Turun, kalau di sekolah harga di atas 2000 itu agak sulit"

Peneliti: "Lha nanti alternatifnya misale itung-itungan ini ternyata biaya produksie lebih besar gimana mas?"

Angga: "Sebetule aku yang utama itu mau ini mau ngasi presentase ke yang kurir itu lo, kan sisteme wes mau tak ganti..." “...jadi aku kan mbayarnya yang bagian produksi borongan a, dari produktivitase de'e jadi per adonan berapa, bukan gaji jadi kelihatan. Dari jurnal dapur dan jurnal pemasaran iku tak jadikan satu ini nanti aku ngeceknya”

Gaji karyawan merupakan salah satu komponen penentu harga jual produk. Gaji karyawan dibayar dengan tiga sistem pengajian. Sistem pertama adalah borongan dimana pembayaran dilakukan berdasarkan produktivitas. Sistem ini diterapkan pada karyawan produksi. Sistem kedua adalah gaji tetap. Sistem ini diterapkan pada kurir. Selanjutnya, sistem ketiga adalah campuran dimana karyawan menerima gaji tetap dan gaji berdasarkan produktivitas. Sistem ini dikhususkan bagi kepala produksi. Berkenaan dengan hal ini, pengecekan atas kesesuaian informasi antara catatan produksi, catatan pemasaran serta catatan kas (termasuk piutang karyawan) merupakan langkah yang ditempuh pemilik bisnis sebelum menentukan besaran gaji masing-masing karyawan. Berdasarkan uraian di atas, catatan memberikan informasi tentang karyawan yang telah melaksanakan kewajiban dan berhak atas pembayaran gaji.

\section{Akuntansi pada fase kedua bisnis: catatan sebagai sumber informasi keuntungan bisnis}

Uraian informan di bawah ini menunjukkan bahwa laba dirumuskan dengan berbasis kas modifikasi. Dalam hal ini, laba dilihat dari jumlah saldo kas ditambah piutang dikurangi hutang. Saldo kas dihasilkan dari transaksi penjualan produk, pembelian bahan, penarikan tunai oleh pemilik, tambahan modal oleh pemilik serta pinjaman yang dilakukan oleh karyawan.

Peneliti: "Samean tau untung rugi darimana mas?"

Terjemahan: "Bagaimana Anda mengetahui usaha memiliki laba atau rugi?"

Angga: "Ya wes anggep lah, lek aku liate dari saldo kas, saldo kas berarti sisa kas. Yang bagian pegang kas iku biasane kan ngasboni arek-arek, nerima hasil penjualan, di luar iku aku njupuk setoran dewe. Misalkan ada temenku yang pesen bayare langsung ke aku, kalau pas aku lewat tak ambil. Jadi komponene ya saldo kas karena saldo kas iku sudah mencakup pembelian dan penjualan terus prive terus aku pernah pergi kemana ko ono bahan murah terus tak tuku terus tak catet pisan modal berarti aku modali maneh dapurku. Terus misalkan aku lewat ono alat-alat seng belum ada di dapurku, jampeljampel, tah plastik opo serbet sekalian tak tuku engko tak itung terus piutang sama utang. Lek ndeloke tekan iku" 
Terjemahan: "Ya anggap lah, kalau saya melihatnya dari saldo kas, saldo kas berarti sisa kas. Yang bagian pegang kas itu biasannya memberi kasbon anak-anak (karyawan), menerima hasil penjualan, di luar itu saya mengambil setoran sendiri. Misalkan ada temen saya yang pesan, bayarnya langsung ke saya, kalau pas lewat saya ambil. Jadi komponennya ya saldo kas karena saldo kas itu sudah mencakup pembelian dan penjualan terus prive terus saya pernah pergi ke mana ada bahan murah terus saya beli terus dicatat sekalian (sebagai) modal berarti saya menambah modal pada dapur saya. Terus misalkan saya lewat (suatu tempat) ada alat-alat yang belum ada di dapur, jampel, plastik atau serbet sekalian saya beli nanti saya hitung terus piutang sama utang. Kalau lihatnya dari itu”).

Metode perhitungan laba ini digunakan oleh informan guna mengompromikan kebutuhan untuk mengetahui jumlah laba dengan keterbatasan informasi terkait nilai depresiasi. Hal ini diungkapkan informan sebagai berikut:

“...cuma waktu sampai ke neraca, laba rugi, aku kesulitane ndek penyusutan iku lo. Lah soalnya toko-toko lek tak takoni iki misalkan lek digawe penyusutan alat per tahun, gak bisa ngomong de'e. yo mungkin de'e ngapik-apikno barange: iki ono seng pirang taun gak rusak-rusak, yo kan repot, itu repote gitu, dadi aku wes gak tertarik nang rugi laba..." Terjemahan: "hanya waktu sampai (penyusunan) neraca, laba rugi, saya kesulitan di penyusutan. Karena toko-toko kalau ditanya ini misalkan kalau dibuat penyusutan alat per tahun, mereka tidak bisa menjawab. Mungkin karena mereka melebih-lebihkan (kualitas) barangnya: ini ada yang bertahun tahun tidak rusak. Ya kan repot, karena itu saya tidak tertarik dengan laba rugi".

Rumusan laba ini dimungkinkan karena tidak terdapat persyaratan bagi pemilik untuk mempertanggungjawabkan keuntungan bisnis kepada pihak lain. Informasi tentang laba hanya diperlukan untuk keperluan pribadi sehingga pemilik bisnis bebas memilih metode yang dapat mewakili keperluan usaha. Secara umum, informan tidak merasa rugi dalam kegiatan bisnis. Berkenaan dengan kerugian, informan hanya mendefinisikan kerugian sebagai hasil dari retur penjualan, produksi tidak teratur serta kerusakan peralatan. Hal ini disampaikan oleh Angga sebagai berikut.

"Sakjane rugine iku paling opo se? optimalisasi tempat, kalau misalkan jadi anggep ja gak akan rugi ko kecuali returnya banyak, gak setiap hari mbikin-kan rugi nilai tempat sama investasi awal, alat rusak. Nek ngomong laba akhire wes gak tak pikir pokoke iki mau gak terganggu yo wes"

Terjemahan: "sebenarnya rugi itu paling apa? optimalisasi tempat, kalau misalkan jadi dianggap saja tidak akan rugi kecuali returnya banyak, tidak setiap hari produksi-kan rugi nilai tempat sama investasi awal, alat rusak. Kalau membicarakan laba akhirnya sudah tidak saya pikirkan asalkan ini tadi tidak terganggu”.

\section{Akuntansi pada Fase Ketiga Bisnis: Kontrak Kerja Melengkapi Fungsi Pengendalian Catatan}

Catatan memainkan peran dalam pengambilan keputusan terkait kontrol kegiatan usaha, harga jual produk, gaji karyawan, serta sumber informasi keuntungan usaha. Sayangnya, beberapa permasalahan belum dapat dipecahkan dengan keberadaan catatan. Hal ini dibuktikan dengan masih munculnya permasalahan tersebut meskipun catatan telah digunakan oleh pemilik usaha. Permasalahan tersebut diungkapkan Angga sebagai berikut:

“..e...gak ono jaminan dari mereka untuk melakukan pekerjaan, dadi misalkan ada pesenan gak digarap lha seng cekat cekot lak kene a. Kemudian masalah ijin juga, lek wes moleh setelah iku njaluk tambah dengan berbagai alasan”.

Terjemahan: (e...tidak ada jaminan dari mereka untuk melakukan pekerjaan jadi misalkan ada pesanan tidak dikerjakan. Yang pusing kan saya. Kemudian masalah ijin juga, kalau sudah pulang minta tambah (ijinnya) dengan berbagai alasan).

Angga juga menjabarkan:

“...kayak ijin, ada itu bagian yang ngirim itu kebetulan dia kan pak RT a, tonggoe mati ijin ndadak. Jenenge wong mati kan ndadak, mang subuh tas mati, dadi sebagai ketua RT kan paling sibuk. Tapi rotie wes siap dikirim sedangkan roti kan gak bisa besok dikirim, kualitasnya sudah drop. Jadi masalah-masalah kemanusiaan kayak gitu, dadi saiki yok opo.?".

Terjemahan: (seperti ijin, ada itu bagian yang mengirim (kurir) kebetulan dia menjabat sebagai ketua RT, tetangganya meninggal, ijin mendadak. Namanya orang meninggal kan mendadak, subuh tadi meninggal, jadi sebagai ketua RT dia paling sibuk. Tapi 
rotinya sudah siap dikirim sedangkan roti tidak bisa dikirim besok, kualitasnya sudah turun. Jadi masalah-masalah kemanusiaan seperti itu, jadi sekarang bagaimana?.).

Pernyataan di atas menunjukkan bahwa permasalahan yang sedang dihadapi perusahaan terletak pada dua hal, yakni kedisplinan karyawan dan norma sosial. Kedisplinan merupakan masalah yang bersumber dari internal karyawan sementara norma sosial (mungkin) menjadi masalah ketika penerapannya menyelisihi kepentingan perusahaan. Dalam dua hal ini, pemilik usaha menilai karyawan kerap mengabaikan kepentingan perusahaan. Yang harus dipahami bahwa penyimpangan dari norma sosial yang menurut perusahaan merupakan solusi permasalahan dapat menimbulkan permasalahan baru bagi pelanggarnya. Keberadaan masalah ini menjelaskan bahwa pada level tertentu catatan kas, catatan produksi, serta catatan pemasaran tidak dapat berfungsi sebagai sarana pengendalian. Berkenaan dengan hal ini, pemilik usaha memutuskan untuk membuat kontrak kerja. Hal ini disampaikan Angga sebagai berikut:

"Sekarang ini aku lagi pusing, beberapa hari ini mau bikin kontrak itu lo jadi meskipun sistem borongan atau outsourching pengen tak gawe kontrak ...bukan hanya masalah jangka waktu yo masalah aturan-aturan”.

Mendasarkan pada pernyataan di atas, kontrak kerja diharapkan menjadi jawaban dari permasalahan yang dihadapi oleh perusahaan. Dalam hal ini, kontrak kerja berisi aturan-aturan tertulis yang jelas dan tegas mengenai hal-hal yang harus ditaati oleh karyawan. Keberadaan aturan tertulis menutup celah bagi alasan-alasan yang diajukan oleh karyawan. Dalam hal ini, baik pemilik usaha maupun karyawan telah secara pasti dan sadar mengetahui hak dan kewajiban masing-masing sehingga dapat dipahami jika ketidaktaatan atas aturan terkait akan membuahkan sanksi bagi pelanggarnya. Di samping itu, kontrak kerja merupakan sarana mengomunikasikan kepentingan kedua belah pihak. Kelebihan kontrak kerja ini yang diharapkan dapat menekan pelanggaran karyawan.

\section{Keadilan: nilai yang terkandung dalam perubahan praktik akuntansi}

Keadilan secara eksplisit disebut informan sebagai tujuan pengelolaan bisnis. Hal ini dapat dicapai melalui keseimbangan antara pengembangan usaha mikro dan kesejahteraan karyawan.

“...sedangkan kita kan kepinginnya adil kan, di satu sisi ada faktor kemampuan usaha, di satu sisi ada faktor tuntutan pekerja”

Sebagai pihak yang tidak memiliki kontak langsung dengan kegiatan bisnis, catatan berfungsi sebagai dasar untuk informasi tentang kondisi bisnis. Keadilan ini diterapkan oleh Angga sebagai berikut:

“...aku mau gaji kalau sudah gak ada masalah karena kalau ada masalah kalau misalkan parah atau karena kelalaian anak-anak si A, Si B, tak kurangi bayarane. Misalkan produktifitasnya cuma 50 dia nulis 60, masak aku mau bayar 60 kan 50 jadi gitu...” “... dari kemampuan usaha, misalkan roti tadi 1700 ya, HPProd 1000 dadi ada 700, nah 700 iku misalkan tiap hari iku minimal ngangkut 150 roti tiap anak iku, titik iku pirang jam kerjo, trus 150 dikali 26 sama dengan 3900 roti, 600 rb dibagi 3900 sama dengan 153. 700 buat dia 150, pantes gak?"

Terjemahan: "dari kemampuan usaha, misalkan roti tadi Rp1.700 ya, HPProd Rp1.000 jadi ada Rp700, nah Rp700 itu misalkan tiap hari minimal mengangkut 150 buah roti tiap anak, sedikit itu cuma berapa jam kerja, terus 150 buah dikali 26 hari sama dengan 3.900 buah roti, Rp600.000 dibagi 3.900 sama dengan Rp153. Rp700 buat dia Rp150, sesuai tidak?".

Pernyataan pertama menunjukkan bahwa catatan produksi dan catatan pemasaran menempati posisi penting dalam memastikan ketercapaian keadilan. Kedua catatan ini menunjukkan bahwa karyawan telah memenuhi kewajiban. Secara khusus, catatan produksi menjelaskan berapa banyak adonan yang dihasilkan per-karyawan sebagai dasar untuk menerima hak dalam bentuk gaji. Berkenaan dengan hal ini, catatan pemasaran digunakan sebagai pembanding yang mengonfirmasi keakuratan informasi jumlah produksi. Pernyataan kedua menunjukkan konsep keadilan diciptakan melalui pengukuran kemampuan pemilik dalam menentukan besaran gaji kurir. Dalam hal ini, pemilik bisnis membandingkan keuntungan yang diperoleh dengan gaji yang diterima oleh kurir, yakni Rp700,00 dibandingkan Rp150,00. Perbandingan ini merupakan penanda bahwa pemilik bisnis memperhatikan kepantasan gaji yang diberikan kepada karyawan. Dengan kata lain, dua pernyataan di atas menunjukkan bahwa apa yang ingin dicapai oleh pemilik bisnis adalah pemenuhan kebutuhan kedua belah pihak. 


\section{SIMPULAN}

Terdapat 3 fase transformasi praktik akuntansi seiring dengan perubahan pola bisnis. Akuntansi pada fase pertama dipraktikan melalui memori. Akuntansi berbasis memori ini terjadi ketika pemilik terlibat langsung dalam pengelolaan bisnisnya. Pada fase kedua dan ketiga, akuntansi sudah dipraktikkan melalui catatan. Catatan akuntansi yang digunakan pada fase kedua adalah catatan kas, catatan produksi dan catatan pemasaran. Pada fase ketiga, kontrak kerja menjadi pelengkap catatan akuntansi yang sudah ada pada fase kedua. Pada fase kedua dan ketiga pemilik tidak terlibat langsung dengan pengelolaan bisnisnya. Ketidakterlibatan secara langsung pemilik usaha atau pendelagasian tugas kepada pihak lain menjadi titik penting transformasi dipraktikannya akuntansi berbasis catatan. Hal lain yang ditemukan dalam praktik akuntansi UMKM ini adalah nilai keadilan. Secara teori, penelitian ini mendukung Teori Insitusional yang menyebut perilaku organisasi, UMKM dalam praktik akuntansi, dipengaruhi oleh faktor internal dan eksternal. Secara praktis, hasil penelitian ini dapat menjadi pertimbangan pelatihan akuntansi yang sesuai dengan kebutuhan dan karakteristik UMKM. Keterbatasan penelitian ini adalah informan tidak memiliki hubungan dengan pihak luar. Dengan demikian, esensi praktik akuntansi yang ditemukan murni mengarah pada pemenuhan kebutuhan internal. Peneliti selanjutnya dapat melibatkan UMKM yang terkait dengan pihak luar seperti bank.

\section{DAFTAR RUJUKAN}

Adian, D. G. (2010). Pengantar Fenomenologi. Depok: Koekoesan.

Alfitri, A., Ngadiman \& Sohidin., S. (2013). Penerapan Standar Akuntansi Keuangan Entitas Tanpa Akuntabilitas Publik (SAK ETAP) pada Usaha Mikro Kecil Menengah (UMKM) Perajin Mebel Desa Gondangsari Kecamatan Juwiring Kabupaten Klaten. Jupe-Jurnal Pendidikan Ekonomi, 2(2), 1.

Andriani, L., Anantawikrama, T.A., \& Ni Kadek, S. (2014). Analisis Penerapan Pencatatan Keuangan Berbasis SAK ETAP Pada Usaha Mikro Kecil Menengah (UMKM) (Sebuah Studi Interpretatif Pada Peggy Salon). Jurnal Ilmiah Mahasiswa Akuntansi Undiksha, 2(1). doi:http://dx.doi. org/10.23887/jimat.v2i1.2254.

Asaduzzaman, M. (2016). Accounting and Financial Reporting Practices of SMEs: Bangladesh Perspective Md. Asaduzzaman. Malaysian Journal of Business and Economics, 3(1), 57-67.

Chelimo,J. K. \& Sopia, I. O. (2014). Effects of Bookkeeping on Growth of Small and Medium Business Enterprises in Kabarnet Town, Baringo County, Kenya. International Journal of Science and Research, 3(12), 432-437. doi:2319-7064.

Darmayanti, N. P. O. A., Nyoman, T. H., \& I. Gusti, A. P. (2017). Implementasi Penyusunan Laporan Keuangan Berdasarkan SAK ETAP dan Penilaian Kinerja pada UMKM Pengrajin Endek Mastuli "Ayu Lestari” di Desa Kalianget Kecamatan Buleleng. E-Journal S1 Ak Universitas Pendidikan Ganesha, 71). doi:10.23887/jimat.v7i1.9584.

Ezeagba, C. (2017). Financial Reporting in Small and Medium Enterprises (SMEs) in Nigeria. Challenges and Options. International Journal of Academic Research in Accounting Finance and Management Sciences, 71), 1-10. doi:10.6007/IJARAFMS/v7-i1/2534.

Failian, A. \& Pepie, D. (2012). Analisis Manfaat Informasi Akuntansi pada UKM di Wilayah Tanggulangin. The Indonesian Accounting Review, 2(1). Doi:10.14414/tiar.v2i01.313.

Fatwa. (2016). Analisis Penerapan SAK ETAP Pada Usaha Kecil Menengah (UKM) Penggilingan Padi. Jurnal Kajian Ilmiah Akuntansi Fakultas Ekonomi UNTAN (KIAFE), 5(4).

Fogarty, T. (1996). The Imagery and Reality of Peer Review in the US: Insights from Institutional Theory. Accounting, Organization and Society. 21(2-3): 243-267. doi:10.1016/0361-3682(95)00001-1.

Gaskill, L. A. R., Howard E. V. A, \& Ronald, A. M. (1993). A Factor Analytic Study of Perceived Causes of Small Business Failure. Journal of Small Business Management.

Groenewald, T. (2004). A Phenomenological Research Design Illustrated. International Journal of Qualitative Methods, 3(1), 1-26. doi:10.1177/2F160940690400300104. 
Haryanti, S., Astuti, D. S. P., \& Harimurti, F. (2019). Implementasi Penyusunan Laporan Keuangan Berdasarkan SAK EMKM. Prosiding Seminar Nasional and The 6th Call for Syariah Paper, Universitas Muhammadiyah Surakarta.

Hofstede, G. (1999). Cultures and Organizations. New York: McGraw-Hill International (UK) Limited. Hopwood, A., Burchell, S., \& Clubb, C. (1994). Value-Added Accounting and National Economic Policy in Accounting as Social and Institutional Practice. A. Hopwood and P.Miller (Eds). Cambridge: Cambridge University Press.

Jacobs, K. \& Kemp, J. (2002). Exploring Accounting Presence and Absent: Case Studies from Bangladesh. Accounting, Auditing; and Accountability Journal, 15(2), 143-161. doi:10.1108/09513570210425592.

Jensen, M. C. \& Meckling, W. H. (1976). Theory of the Firm: Managerial Behavior, Agency Costs and Ownership Structure. Journal of Financial Economics, 3(4), 305-360. doi:10.1016/0304405X(76)90026-X.

Kuswarno, E. (2009). Metodologi Penelitian Komunikasi Fenomenologi: Konsepsi, Pedoman, dan Contoh Penelitiannya. Bandung: Widya Padjadjaran.

Laily, N. (2013). Praktik Akuntansi pada Bisnis Retail: Sebuah Studi Fenomenologi. Jurnal Modernisasi, 9(3), 161-168. doi:10.21067/jem.v9i3.181.

Lutfiaazahra, A. (2015). Implementasi Standar Akuntansi Keuangan Entitas Tanpa Akuntabilitas Publik (SAK ETAP) pada UMKM Pengrajin Batik di Kampoeng Batik Laweyan Surakarta. Prosiding Seminar Pendidikan Ekonomi dan Bisnis.

Madurapperuma, M. W., Thilakerathne, P. M. C., \& Manawadu, I. N. (2016). Accounting Record Keeping Practices in Small and Medium Sized Enterprise's (SME's) in Sri Lanka. Journal of Finance and Accounting, 4(4), 188. doi:10.11648/j.jfa.20160404.14.

Maseko, N. (2011). Accounting practices of SMEs in Zimbabwe: An Investigative Study of Record Keeping for Performance Measurement (A Case Study of Bindura). Journal of Accounting and Taxation, 3(8), 171-181. doi:10.5897/JAT11.031.

Mbroh, J. K., \& Assah, B. (2015). Financial Management Practices by Small and Micro Enterprise Owners in Ghana - Evidence from the Central Region. International Journal of Economics, Finance and Management Sciences, 3(5), 494. doi:10.11648/j.ijefm.20150305.21.

Moleong, L. J. (2000). Metodologi Penelitian Kualitatif. Bandung: PT Remaja Rosdakarya.

Mulyani, A. S. (2018). Manfaat Informasi Akuntansi Dalam Perkembangan Usaha Mikro Kecil dan Menengah. Jurnal Ekonomi, Manajemen dan Bisnis Universitas Bina Sarana Informatik, 2(1).

Norkamsiah, Kesuma, A. I., \& Setiawaty, A. (2016). Penerapan Standar Akuntansi Keuangan Entitas Tanpa Akuntabilitas Publik (SAK ETAP) pada Penyusunan Laporan Keuangan. Jurnal Ekonomi Dan Keuangan, 13(2). doi:10.29264/jakt.v13i2.1181.

Nurlela \& Elvia, H. (2016). Penerapan Laporan Keuangan Usaha Kecil Menengah Berbasis SAK ETAP pada Toko Jamu Nikisami. Jurnal Bisnis Administrasi, 5(2), 60-66.

Nuvitasari, A., Citra, N., \& Martiana, N. (2019). Implementasi SAK EMKM Sebagai Dasar Penyusunan Laporan Keuangan Usaha Mikro Kecil dan Menengah (UMKM). International Journal of Social Science and Business, 3(3), 341-347.

Nyathi, K. A., Nyoni, T., Nyoni, M., \& Bonga, W. G. (2018). The Role of Accounting Information in the Success of Small \& Medium Enterprises (SMEs) in Zimbabwe: A Case of Harare. Journal of Business and Management (DRJ-JBM), 1(1), 1-15.

Pambudi, E. D. \& Adam., H. (2013). Penerapan Standar Akuntansi Keuangan Entitas tanpa Akuntabilitas Publik (SAK ETAP) pada Laporan Keuangan Usaha Mikro, Kecil dan Menengah (Studi pada Usaha Sari Apel, Kota Batu). Jurnal Ilmiah Mahasiswa FEB Universitas Brwaijaya, $1(2)$.

Patton, M. Q. (2002). Qualitative Research and Evaluation Methods. California: Sage Publications. 
Rudiantoro, R. \& Siregar, S. V . (2012). Kualitas Laporan Keuangan UMKM serta Prospek Implementasi SAK ETAP. Jurnal Akuntansi Dan Keuangan Indonesia, 9(1), 1-21. doi:10.21002/jaki.2012.01.

Saragih, F. \& Surikayanti. (2015). Analisis Penerapan Akuntansi dan Kesesuaiannya dengan SAK ETAP pada UKM Medan Perjuangan. Seminar Nasional Ekonomi Manajemen dan Akuntansi (SNEMA) Fakultas Ekonomi Universitas Negeri Padang.

Scott, W. R. (2003). Financial Accounting Theory, 3^rd. Prentice Hall.

Zucker, L. G. (1987). Institutional Theories of Organization. Annual Review of Sociology, 13, 443464. doi:10.1146/annurev.so.13.080187.002303. 